Copyright (C) 2016 by Academic Publishing House Researcher

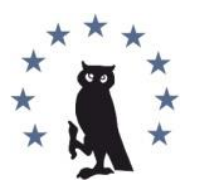

Published in the Russian Federation

European Researcher

Has been issued since 2010.

ISSN 2219-8229

E-ISSN 2224-0136

Vol. 110, Is. 9, pp. 494-499, 2016

DOI: 10.13187/er.2016.110.494

www.erjournal.ru

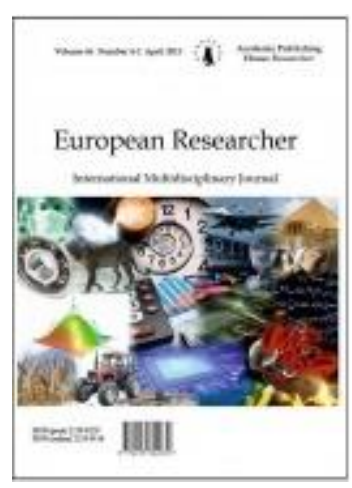

UDC 930.85

\title{
Science and Religion in the Russian Federation nowadays: Conflict or dialogue?
}

\author{
German E. Bokov
}

\begin{abstract}
Saint-Petersburg State University, Russian Federation
Mendeleevskaya liniya 5, St. Petersburg, 199034

$\mathrm{PhD}$ (Philosophy), Associate Professor

E-mail: bokovg@gmail.com
\end{abstract}

\begin{abstract}
The article discusses the main aspects of the relationship between science and religion in the Russian Federation nowadays. It shows an official position of the Russian Orthodox Church concerning the latest scientific developments, secular culture, and education as well as separate views of different scientists, theologians, and philosophers about it. In particular, the paper examines reaction from academic community in the Russian Federation towards some attempts of introduction of theology in to secular space science and education. This article introduces different points of view about the problem of choice of the world view reference points in contemporary conditions when Christian theology substantiates the necessity of science and religion interaction.

Keywords: science and religion, the Russian Orthodox Church, theology, religious studies, secular culture, a human being, technology, violence, atheism, ethics.

1. Introduction

Today "Science and Religion" is one of the most popular subjects in academic and public spheres in many countries all over the world. A number of publications by researchers, philosophers, and theologians are dedicated to this subject. Some of them speak with atheistic position opposing science to religion. However, most of them are protestant theologians which insist on dialogue between science and religion in contemporary world. In general, this tendency is also typical to catholic and orthodox thinkers.

As in other European countries, in the Russian Federation the problem of the relationship between science and religion is quite acute, but the character of building of this relationship in Russian society is quite specific. Therefore, in this paper I would really like to discuss some of the most important and specific points of the relationship between science and religion in the Russian Federation nowadays.
\end{abstract}

\section{Materials and Methods}

The article is based on analysis of an official position of the Russian Orthodox Church concerning the latest scientific developments, secular culture, and education as well as separate opposite views of some scientists towards this issue. The methodological basis for the paper is the principle of scientific objectivity. In this study author used hermeneutic, socio-critical, descriptive and historically-typological approaches as well as qualitative methods of social studies. In the 
analysis of social, cultural, and political aspects of contemporary Russian realities submitted by materials of mass media, and Internet resources the different points of the relationship between science and religion in the Russian Federation nowadays are reflecting.

\section{Discussion}

There are different points of view about the relationship between science and religion. Russian orthodox philosophers, such as Semyon Frank emphasized that science and religion cannot oppose each other because they are "absolutely different matters". Frank said, "All conversations about absence of harmony between them resulted from both ignorance and stupidity" [1, p. 3]. On the contrary, the main tendency in Soviet historiography was categorical opposition of science and religion as important factors of "ideological struggle". The atheistic literature told about the conflict among them for the right to form a world's paradigm. There was emphasized the truth of scientific knowledge as opposite to religion faith.

Today both these points still exist. However, with a change of position of the Russian Orthodox Church in post-Soviet Russia the opinion about science and religion's dialogue begins being introduced in society. Sometimes such persistence leads to the negative reaction among some atheists-scientists and also causes some misunderstanding in the society. In particular, it has to do with some changes of contemporary Russian education.

In august two-thousand was held the Jubilee Council of Bishops of the Moscow Patriarchate of the Russian Orthodox Church. There were adopted "the Basis of the Social Concept". It is an official document about different points of the relationship between the Church and the contemporary secular world. In particular, it focused on science as "one of the most important components of culture" [2].

It says that science is the result of development of Christian thought. However, "despite Christianity's initial impact" later the development of science and technology was carried out under the influence of "secular ideologies" [2]. According to the position of the Russian Orthodox Church, in the eighteenth century some "atheistically-minded thinkers" "resolutely opposed science to religion". It was a result of "faith in the omnipotence of the scientific knowledge" [2]. The Church has condemned this opinion calling it "the false principle". It warns that if science wasn't "restricted by any ethical, philosophical, or religious requirements" it would result in a global disaster [2]. In this sense in Christian theology as well as in postmodern philosophy revaluation of the age of Enlightenment with main concept of "progress" took place.

Really, "Knowledge is power" - it is a great slogan of the Modern European culture and thought. However, the reverse side of progress was blood and thunder, weapons, wars, intervention in the universal laws of a human nature, and the Universe, especially in the XX-th century. In fact, we must recognize that science and technology have made the violence more widespread and ruthless. After the two World Wars a nuclear threat remains relevant as a result of scientific work. Thus history itself raised a fundamental question about responsibility of a scientist who must follow humanistic goals.

Therefore, the Russian Orthodox Church underlines that by the end of the twentieth century science and technology have achieved such influence on all aspects of life as to become "the decisive factors in the life of the civilization" [2]. Consequently, the Church says "to ensure normal human life" it is necessary today as never before "to restore the lost link of scientific knowledge with the religious, spiritual and moral values" [2]. The Church insists on dialogue between science and religion "for the save of life and its proper order" [2].

However, there is another position. A number of scientists-atheists publicly assumed that theology shouldn't intrude into secular science. In particular, in two thousand and seven was published the open letter to the President of the Russian Federation from ten academicians, the Members of the Russian Academy of Sciences. They were notable scientists such as Nobel laureates in physics Vitaly Ginzburg and Zhores Alferov. They expressed their concern about so-called "increasing clericalization of Russian society" that is "the Church's infiltration of all areas of public life" [3]. They affirmed wide discussion of the issue of dialogue between science and religion is a result of clericalization supported by State. This letter said that in-admissibility for the Russian Orthodox Church to interfere in the secular area of science and education. They emphasized their "respect for the feelings of religious people" and that their goal "is not to fight religion". However, 
they affirmed there wasn't alternative to scientific knowledge and opposed so-called "knowledge substitute" for the faith [3].

In the first place, in this letter the authors expressed their attitude towards contemporary Russian education. These academicians were against "the Church's attempts to introduce theology in the list of government-recognized scholarly subjects". They proved that theology being "an assemblage of religious dogmas" and shouldn't be one of scientific subjects [3]. So, this letter illustrated the negative reaction of the some representatives of academic community of Russia to the persistence of the Church in public life, science, and education.

Actually, in recent years in Russia have appeared a lot of theology's educational programs as well as theological departments. Until now they have never existed in Russian State Universities. The Orthodox theologians and priests were always prepared by Orthodox Academies. This always distinguished Russia from other European countries where theology was originally part of classical European university education. Today besides Orthodox Academies in the Russian Federation there are a number of special private universities and institutes with theology as a priority academic direction. However, the problem is that theology as academic direction has being introduced in State' system of higher education.

It means, sometimes theology begins being understood not only as the doctrine of God built on the basis of the Scripture. Today theology as an educational humanities program claims to be a part of the complex of knowledge about religion which used to be a problematic field of religious studies. Therefore, in contemporary Russian society the following question has being discussed: is theology really an independent branch of the humanities along with religious studies, or not? [4].

In two thousand and eleven was held the Council of Bishops of the Moscow Patriarchate of the Russian Orthodox Church. There were adopted the new decision about improving both dialogue between the Church and secular science. A short time before the Patriarch of Moscow and all Rus' Kirill visited National Research Nuclear University (Moscow Engineering Physics Institute). It's one of the fundamental scientific Centers of Nuclear Physics and important technical educational center in Russia. An Orthodox Church was established there a few years ago. The Patriarch Kirill was sanctified this Church gave a lecture about relationship between science and religion for both students and teaching staff and was made an honorary doctor of Moscow Engineering Physics Institute. After two years the Department of theology was opened in this technical University among other aimed to discussion of the relationship between science and religion. However, most of scientists and students were against all these events. They assumed that the Church shouldn't intrude in secular science. [5]

The problem is complicated by a question of a school education. Really, "from the Orthodox perspective it is desirable that the entire educational system should be built on religious principles and based on Christian values" [2]. Although in the same place emphasized that the Church "respects the secular school" as well as a human freedom but it considers "it inadmissible to impose on students anti-religious and anti-Christian ideas and to assert the monopoly of the materialistic view of the world" [2]. On the contrary, the letter by ten academicians says, "all achievements of worldwide modern science are based on a materialistic view of the world. There is simply no other thing in modern science" [3].

One of the authors of the letter academician Vitaly Ginzburg guessed the science and religion should avoid each other. He is known as a critic of religion and popularizer of the secular humanism and principles of the freedom of conscience. Speaking as an atheist, he noted that politics of Bolshevism discredited atheism "which in essence has nothing to do with violence" [6]. On the contrary, the Christian Church has always condemned scientific knowledge. Ginsburg wrote that to identify all atheists with those Bolsheviks "militant atheists", who shot believers, is equivalent to identify all Christians with the Inquisition, or all Muslims with fundamentalists and terrorists [6]. According to him the age of Enlightenment was a period of beginning widespread acceptance of humanism, materialism and progressive scientific knowledge. According to him secular ethics doesn't need religious doctrines [6].

Academician Ginzburg and other scientists especially emphasized that creationism should not be taught in schools in any form. It should be noted that Darwin's theory of evolution is still the most painful issue for the Orthodox theology and Orthodox believers. The official position of the Russian Orthodox Church on this issue does not exist. There are only separate positions of modern Orthodox theologians. 
In two-thousand and six a well-known case was held in Russia. A fifteen year old schoolgirl Masha Schreiber, and her father, were speaking against the non-alternative "imposition" of the theory of evolution in school's course of biology which is contrary to her religious faith. Although St. Petersburg court rejected the claim to prohibition of teaching of the evolutionism, the case became a major focus of public attention, and was discussed for a long time [7].

In two-thousand and thirteen a group of Orthodox young people made a flashmob against the theory of evolution at the State Darwin Museum in Moscow. Their leaflets told that the world was created by God seven thousand five hundred twenty two years ago. Also they demanded to bring "religious instruction" in every school. It is even more interesting that one of the leaflets contained the text about the theory of evolution as a real threat. It was called a pseudoscientific myth which Trotsky and Hitler followed to justify the murder of millions of people [8].

This flashmob received a numbers of negative responses on the Internet. For Orthodox culture it was unique. It looked like an action of Protestant creationists in the USA many years ago and in general as a rule it is condemned by Orthodox believers. So, it was supported only by a few Orthodox priests. A lot of theologians were against this flashmob such as one of the most popular and influential contemporary Orthodoxy theologians Andrey Kuraev [9]. In one of his papers "Orthodoxy and evolution" he argues that "in Orthodoxy there are no textual or doctrinal reasons for the rejection of evolution". According to him "the Lord created matter which is able to the benefits of the development" [10].

One more problem which is discussed in modern society even more widely is the problem of the use of biomedical technologies. Here the Church has a clear official position which is shared by almost all orthodox theologians. Particularly, in this point it is most significant that the understanding of good and evil in the modern Christian thought is contrary to ethics of liberal secular humanism.

In fact, the rapid development of biomedical technologies which have invaded the life of modern man rises nowadays in front of society serious questions about boundaries of tolerance. "The Basis of the Social Concept" of the Russian Orthodox Church says that this development without spiritual moral bases "can bring to humanity new burdens and suffering" [11]. The Church insists that "proceeds from the ideas of life based on the Divine Revelation. It asserts life as a precious gift of God". It noticed that "the growing technological interference in the conception of human life presents a real threat to the spiritual integrity and physical health of a person" [11].

Thus, the Church strongly condemns abortion as a grave sin, and different manipulations of reproductive medicine such as donation of germ, surrogate motherhood as well as a change of the human genome, the cloning of the human being, foetal therapy, euthanasia, sex reassignment surgeries, and others things of new medicine technologies. In this case, it is emphasized that not medicine is condemned as such, but a human choice of "a distortion of the God-created human nature" [11]. The Russian Orthodox Church and contemporary Orthodox theology of science reasoning from today's realities very clearly define their position towards the saving of Christian values, human life, traditional family, freedom, and responsibility as well as the sin.

\section{Conclusion}

In such a way, we can come to the following conclusions.

In Russia as in other European countries, the problem of relationship between science and religion is being very acute last decades. This is one of the most important subjects in both academic studies and public discussions. In particular, it has to do with some changes of contemporary Russian education.

On the one hand, the importance of scientific discoveries of modern theology is scarcely contested. In general, Christian theology is trying to find correct explanation for scientific theories. However, on the other hand, the Russian Orthodox Church opposed "the monopoly of the materialistic view on the world". In turn, a number of "atheistically-minded" scientists resolutely oppose it.

Unfortunately, a gap between secular liberalism and Christian conservatism is increasing. Certainly, the problem of the relationship between science and religion has not only theological or ethical issues, but also social and political aspects. But I believe that definition of basic human values and principles today is fundamentally important for people all over the world. Actually, 
today the need for a new world view promoted the successful interaction between science and religion [12, pp. 5-6].

Indeed, the impact of science and technology on the process of the formation of a personality and society nowadays is infinite and it will only increase. It has always been the most important factor of secularization. In fact, such influence of science and technology to humanity in the twenty first century also carries a potential threat to the essence and existence of a human being. So, for this reason it is necessary for Orthodox Christian theology to understand the modern reality. Thus it leads Christian theology all over the world including Russia to the development and popularization of discussions about relationship between science and religion.

\section{Acknowledgements}

The publication was prepared with the support of the grant of Russian Foundation for Humanities № 16-33-01186 "Religion, Science and Education in the Russian Federation nowadays".

\section{References}

1. Frank, Semen L. Religiya i nauka [Religion and Science] // Religiya, filosofiya i nauka. Bryussel'. 1953, № 1, pp. 1-26.

2. Osnovy sotsial'noi kontseptsii Russkoi Pravoslavnoi Tserkvi. XIV. Svetskie nauka, kul'tura, obrazovanie [The Basis of the Social Concept of the Russian Orthodox Church. XIV. Secular science, culture and education] [online] // Available from: http://www.patriarchia.ru/db/text/141422.html (accessed 10.09.2016).

3. Otkrytoe pis'mo prezidentu Rossiiskoi Federatsii V.V. Putinu [The open letter to the President of the Russian Federation from ten academicians, the Members of the Russian Academy of Sciences] [online] // Available from: http://scepsis.net/library/id_1346.html (accessed 10.09.2016).

4. Shakhnovich, Marianna M., Shmonin, Dmitry V. Teologiya i religiovedenie v sovremennoi Rossii: praktika obrazovatel'noi deyatel'nosti [Theology and religious studies in contemporary Russia: the practice of educational activities] // Vestnik Russkoi khristianskoi gumanitarnoi akademii. 2013, Vol. 14, Is. 1, pp. 253-255.

5. Some Internet news [online] // Available from: http://www.vesti.ru /doc. html?id=345474\&photo_id=409336\&p=3\&fr=1 http://www.patriarchia.ru/db/text/1106478.html https://mephi.ru/special/press/news/1387/9202/ http://www.religiopolis.org/news/149-miphizastav-rektorat-bogu-molitcya-on.html (accessed 10.09.2016):

6. Ginzburg, Vitaly L. Ob ateizme, religii i svetskom gumanizme [About atheism, religion and secular humanism.] Moscow: Librokom, 2011. See [online:] Vera v Boga nesovmestima $s$ nauchnym myshleniem [Faith in God is incompatible with scientific thinking] // Available from:

http://www.atheism.ru/library/Ginzburg_2.phtml (accessed 10.09.2016):

7. Some Internet news [online] // Available from:

http://www.fontanka.ru/2007/05/29/o89/ https://rg.ru/sujet/2842/

http://www.gazeta.ru/2006/10/26/oa_221708.shtml

religion.ru/print.php?act=print_media\&id $=3146$ (accessed 10.09.2016).

http://www.interfax-

8. Some Internet news [online] // Available from:

https://www.ridus.ru/news/73497.html

http://macroevolution.livejournal.com/116402.html

http://annya-writer.livejournal.com/1097.html (accessed 10.09.2016).

9. See online: http://diak-kuraev.livejournal.com/455521.html?page $=3$ (accessed 10.09.2016)

10. Kuraev, Andrey V. Orthodoxy and evolution [online] // Available from: http://svitk.ru/o04_book_book/15b/3407_kuraev-pravoslaviya_i_evolyuciya.php___accessed 10.09.2016).

11. Osnovy sotsial'noi kontseptsii Russkoi Pravoslavnoi Tserkvi. XII. Problemy bioetiki [The Basis of the Social Concept of the Russian Orthodox Church. XII. Problems of bioethics] [online] // Available from: http://www.patriarchia.ru/db/text/141422.html (accessed 10.09.2016).

12. Kasavin, Ilya T. Vvedenie. O vozmozhnosti novogo napravleniya issledovanii: "Science \& Spirituality" [Introduction by Ilya Kasavin. On the possibility of a new research trend: "Science \& 
Spirituality"] // Nauka i religiya. Mezhdistsiplinarnyi i kross-kul'turnyi podhod. Moscow: "Kanon +“, ROOI "Reabilitatsiya“, 2006, pp. 5-10.

УДК 930.85

\section{Наука и религия в современной России: конфликт или диалог?}

Герман Евгеньевич Боков

Санкт-Петербургский государственный университет, Российская Федерация

199034 Санкт-Петербург, Менделеевская линия, д. 5

Кандидат философских наук, доцент

E-mail: bokovg@gmail.com

Аннотация. В статье рассматриваются основные аспекты взаимоотношений между наукой и религией в современной России. В ней представлена как официальная позиция Русской Православной Церкви в отношении новейших научных достижений, светской культуры и образования, так и отдельные взгляды разных ученых, философов и богословов. В частности, в статье рассматривается реакция, существующая в академическом сообществе Российской Федерации, в отношении некоторых попыток внедрения теологии в секулярную сферу науки и образования. В статье отражены различные точки зрения на проблему выбора мировоззренческих ориентиров в современных условиях, когда христианской теологией обосновывается необходимость взаимодействия религии и науки.

Ключевые слова: наука и религия, Русская Православная Церковь, теология, религиоведение, светская культура, человеческое бытие, технология, насилие, атеизм, этика. 